\title{
The Ameliorative Potential of Probiotics and/or Silymarin on Thioacetamide Induced Hepatotoxicity in Rats: Histological and Immunohistochemical Study
}

\author{
El Potencial de Mejora de los Probióticos y/o Silimarina sobre la Hepatotoxicidad \\ Inducida por Tioacetamida en Ratas: Estudio Histológico e Inmunohistoquímico
}

Mahmoud Abdelghaffar Emam'; Sameh Mohamed Farouk² \& Mohamed Abdo ${ }^{3}$

EMAM, M. A.; FAROUK, S. M. \& ABDO, M. The ameliorative potential of probiotics and/or silymarin on thioacetamide induced hepatotoxicity in rats: histological and immunohistochemical study. Int. J. Morphol., 36(2):661-669, 2018.

SUMMARY: Thioacetamide (TAA) is one of the common fungicidal agents that induce liver injury varying from inflammation, necrosis, and fibrosis to cirrhosis. Many recent studies reported the beneficial effect of probiotics and silymarin on hepatotoxicity regardless the causative agents. Therefore, the present study aimed to evaluate the ameliorative role of probiotics and/or silymarin on TAA induced hepatotoxicity in rats via histological, and immunohistochemical methods. Twenty five male albino rats were used for this experiment and were divided into five groups ( $\mathrm{n}=5$ rats/group); group I acts as negative control, group II was orally administrated distilled water for six weeks, then injected with TAA (200 mg/kg b.wt./ $5 \mathrm{ml}$ physiological saline/ I.P.) twice a week for another six weeks, group III was treated with probiotics at a dose of $135 \mathrm{mg} / \mathrm{kg}$ b.wt. orally in drinking water daily for six weeks, then injected with TAA (dosage of group II), twice weekly for another six weeks, group IV was treated with silymarin at a dose of $200 \mathrm{mg} / \mathrm{kg}$ b.wt orally 4 times per week for six weeks, then injected with TAA (dosage of group II), twice weekly for another six weeks and group V was treated with combination of both probiotics and silymarin, at the same dosage in groups III and IV respectively then injected with TAA (dosage of group II), twice weekly for another six weeks. Histologically, TAA induced hepatocytes degeneration, inflammatory cells infiltration, and pseudolobular parenchyma as well as, high apoptosis and low proliferation rates that were proved by immunohistochemical staining for caspase 3 and ki-67 respectively. Probiotics and/or silymarin improved the histological feature of hepatocytes, reduced apoptosis and stimulated proliferation. Based on these results, we concluded that the use of probiotics and silymarin combination ameliorates the hepatotoxic effect of TAA in rats more than the use of probiotics or silymarin alone.

KEY WORDS: Thioacetamide; Probiotics; Silymarin; Liver; Histology; Immunohistochemistry.

\section{INTRODUCTION}

Liver plays important roles in metabolism, detoxification, secretion, and storage (Wallace et al., 2008). Hepatotoxicity implies chemical or drug induced liver damage that is considered as a cause of acute and chronic liver diseases (Ostapowicz et al., 2002). Histological patterns of hepatotoxicity vary from zonal necrosis, hepatitis, fibrosis, and neoplasm (Mumoli et al., 2006).

Thioacetamide (TAA) is an organo-sulfur compound that is well known as hepatotoxin (Aydin et al., 2010). It is commonly used as a fungicide to control the decay of citrus fruits especially orange (Lee et al., 2003), as organic solvent in leather industry (Pohanish, 2012) and in preparation of nano-composites (Housková et al., 2007). So, potential occupational exposure to TAA may occur via dermal contact and/or inhalation (Al-Attar, 2011). Model of TAA induced liver injury is widely used to study the acute hepatotoxicity and chronic hepatitis and fibrosis (Bataller \& Brenner, 2005).

As the World Health Organization reported lack of safe modern drugs (Ayyanar et al., 2008), there is a considerable interest in finding natural drugs for the treatment of liver diseases to be added in foods or medicinal materials instead of synthetic ones.

\footnotetext{
${ }^{1}$ Histology and Cytology Department. Faculty of Veterinary Medicine, Benha University, 13736 Egypt.

${ }^{2}$ Cytology and Histology Department, Faculty of Veterinary Medicine, Suez Canal University, 41522 Ismailia, Egypt.

${ }^{3}$ Anatomy and Embryology Department. Faculty of Veterinary Medicine, University of Sadat City, 32511 Egypt.
} 
Probiotics are beneficial live microorganisms to health if administered in adequate amount (Sanders et al., 2014). For animals, they are used as therapeutic, prophylactic and growth promoters (Anukam et al., 2006). Recently, the intake of probiotics is recommended for those have disturbance of liver enzymes activities (Takei, 2013).

Silymarin is one of the promising herbs showing activity in treating liver diseases (Stickel \& Schuppan, 2007). It has anti-oxidative, anti-inflammatory, anti-fibrotic, and liver regenerative effect (Thyagarajan et al., 2002).

So, the present study aimed to evaluate the ameliorative potential of probiotics and/or silymarin in treating TAA induced hepatotoxicity in rats via histological and immunohistochemical assessment.

\section{MATERIAL AND METHOD}

\section{Chemicals}

1. TAA was purchased from El-Gomhouria company for trading chemicals, medicines and medical appliances, Cairo, Egypt. It was manufactured by Loba. chemi. Co, Delhi, India.

2. Probiotics were kindly supplied form New Dynovet Free Trade and manufactured by Multipharm company, Cairo, Egypt. Probiotics were mixture of Lactobacillus, Saccharomyces, Aspergillus, Streptococcus, Bifidobacterium and Torulopsis species in addition to amylase, Xylanase and lactose.

3. Silymarin was purchased from SEDICO pharmaceuticals company, Cairo, Egypt, as sachets.

Animals and experimental design. Twenty five albino male rats of $200 \pm 20 \mathrm{~g} \mathrm{~b}$. wt. were obtained from lab animal house, Faculty of Veterinary Medicine, Benha University, Egypt. Rats were housed in separate metal cages and left 15 days for acclimatization after that they were divided in to five groups:

Group I (Control negative): Rats $(\mathrm{n}=5)$ were orally administrated distilled water for six weeks then injected intraperitoneally with normal saline daily for another six weeks.

Group II (TAA): Rats $(\mathrm{n}=5)$ were orally administrated distilled water for six weeks then injected with TAA (200 $\mathrm{mg} / \mathrm{kg}$ b.wt/ $5 \mathrm{ml}$ physiological saline/ I.P.), twice weekly for another six weeks according to the method of Hsieh et al. (2008). These rats were kept as positive control group.

Group III (Prob.): Rats $(\mathrm{n}=5)$ were treated with probiotics at a dose of $135 \mathrm{mg} / \mathrm{kg}$ b.wt. orally in drinking water daily for six weeks according to Velayudham et al. (2009) then injected with TAA $(200 \mathrm{mg} / \mathrm{kg}$ b.wt/ $5 \mathrm{ml}$ physiological saline/ I.P.), twice weekly for another six weeks.

Group IV (Sily.): Rats $(\mathrm{n}=5)$ were treated with silymarin at a dose of $200 \mathrm{mg} / \mathrm{kg}$ b.wt orally 4 times per week for 6 weeks according to Muriel et al. (2005), then injected with TAA (200 mg/ kg b.wt/ $5 \mathrm{ml}$ physiological saline/ I.P.), twice weekly for another six weeks.

Group V (Sily. + Prob.): Rats $(\mathrm{n}=5)$ were treated with combination of both probiotics and silymarin at the same dosage in groups III and IV respectively then injected with TAA ( $200 \mathrm{mg} / \mathrm{kg}$ b.wt/ $5 \mathrm{ml}$ physiological saline/ I.P.), twice weekly for another six weeks.

Tissue collection. Rats of all groups were sacrificed by decapitation then their livers were rapidly excised and rinsed with isotonic saline. From each liver, tissue samples were collected for histological and immunohistochemical examinations.

Histological examination. Liver specimens were immersed in $10 \%$ neutral buffered formalin for $48 \mathrm{~h}$ then, dehydrated in ascending grades of ethyl alcohol, cleared in xylene, and embedded in paraffin blocks. Paraffin sections were cut into 5-7 $\mu \mathrm{m}$ thickness then deparaffinized and rehydrated using the standard techniques according to Bancroft \& Gamble (2002). Liver sections were stained with hematoxylin and eosin (H\&E) for general structure and assessment of histological changes. However, the degree of liver fibrosis in the sections was evaluated by Masson's trichrome stain.

Immunohistochemical technique. Paraffin sections were collected into positive slides and processed for immunohistochemical examination using a streptavidinbiotin-peroxidase method according to Horiguchi et al. (2007). Deparaffinization and hydration were done before antigen retrieval which was performed by heating the slides in citrate buffer ( $\mathrm{pH}$ 6.0) for $15 \mathrm{~min}$ in a steamer. To block endogenous peroxidase activity, slides were dipped in absolute methanol containing $3 \%(\mathrm{v} / \mathrm{v})$ hydrogen peroxide for $10 \mathrm{~min}$ at RT. Sections were then incubated overnight at $4{ }^{\circ} \mathrm{C}$ with monoclonal mouse anti-ki-67 (clone MM1, Novocastra Laboratories Ltd, UK) and poloclonal rabbit anti-caspase 3 (Asp175, Cell Signalling Technology Inc., MA, USA) at dilution of 1:100. Next, sections were exposed 
EMAM, M. A.; FAROUK, S. M. \& ABDO, M. The ameliorative potential of probiotics and/or silymarin on thioacetamide induced hepatotoxicity in rats: histological and immunohistochemical study. Int. J. Morphol., 36(2):661-669, 2018.

to biotinylated goat anti-rabbit IgG (Dako, USA) or rabbit anti-mouse IgG (Dako, USA) diluted 1: 200 for $30 \mathrm{~min}$ at RT. Visualization was done using commercial peroxidase streptavidin complex (ABC; Dako, USA) for 30 min then 3,3'-diaminobenzidine tetrahydrocholoride (DAB; Dako, USA) for $2 \mathrm{~min}$ at RT. Finally, the sections were counterstained with hematoxylin. Negative control sections were incubated with normal goat or rabbit serum instead of the primary antibodies (Dako, USA).

\section{RESULTS}

Histological findings. Liver obtained from control negative animals revealed normal hepatic architecture where normal hepatocytes were arranged into radiating hepatic cords from the central veins. Besides, normal blood sinusoids were enclosed in between hepatic cords (Fig. 1A).

Liver sections of group II showed an abnormal histological feature. Numerous and thick interlobular connective tissue septa were identified (Fig. 1B). The stained sections with Masson's trichrome demonstrated pseudolobular parenchyma that was surrounded by obvious collagen fibers of the interlobular septa (Fig. 1C) in addition, it was infiltrated with inflammatory cells (Fig. 1D). Congestion of blood sinusoids and Macrophagocytus stellatus (Kupffer cells) proliferation were detected in between the hepatocytes that were degenerated and showed cytoplasmic vacuolation (Fig. 1D). The portal area manifested severe congestion of the portal vein, inflammatory cells infiltration (Fig. 1E), and fibrosis around the bile duct (Fig. 1F).
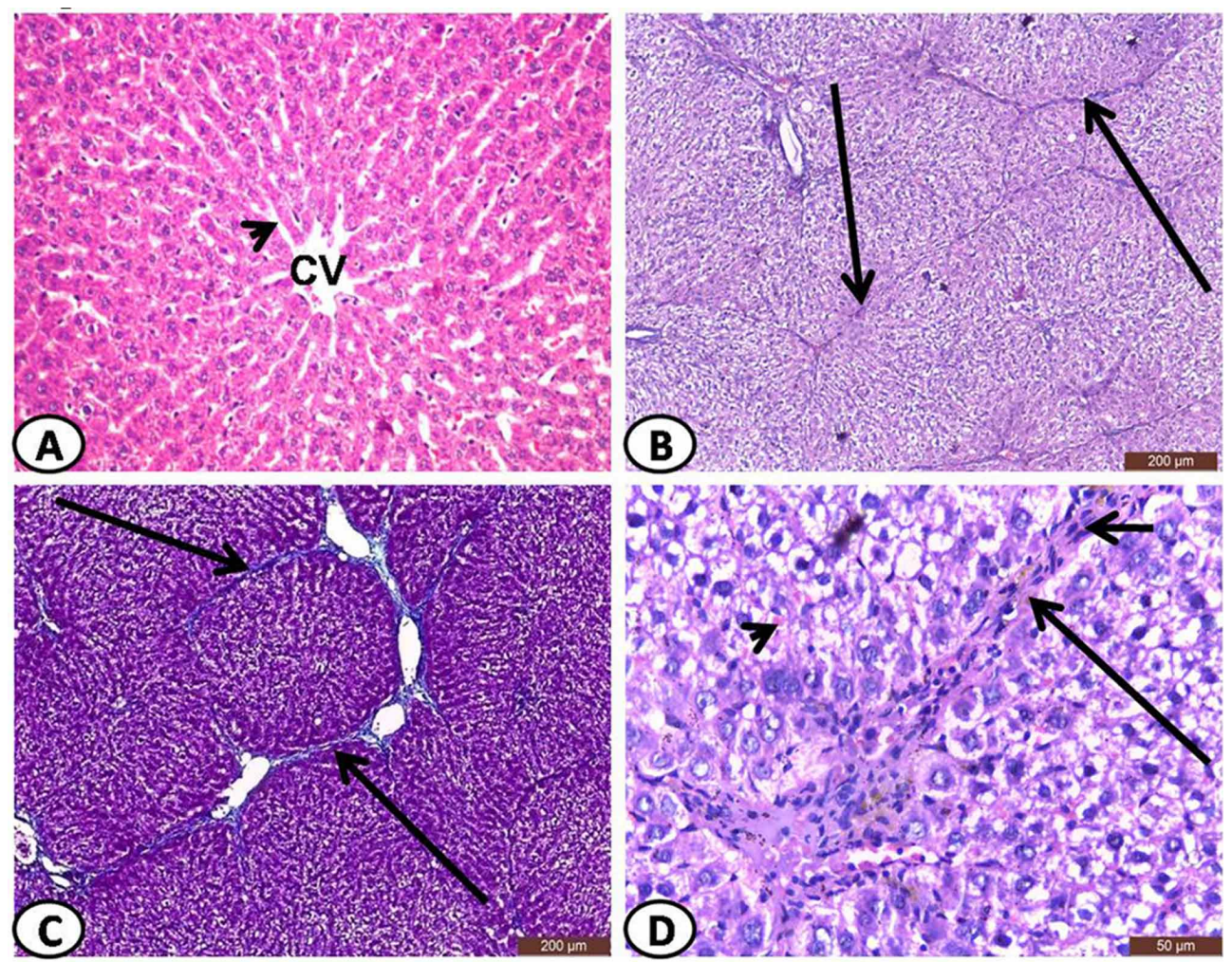

Fig. 1. Representative photomicrographs of livers obtained from control negative group (A) and thioacetamide treated group (B-F). CV, central vein; arrowhead, blood sinusoids; long arrow, interlobular septa; short arrow, inflammatory cells; PV, portal vein; BD, bile duct. All sections stained with H\&E except Figs. C and F stained with Masson's

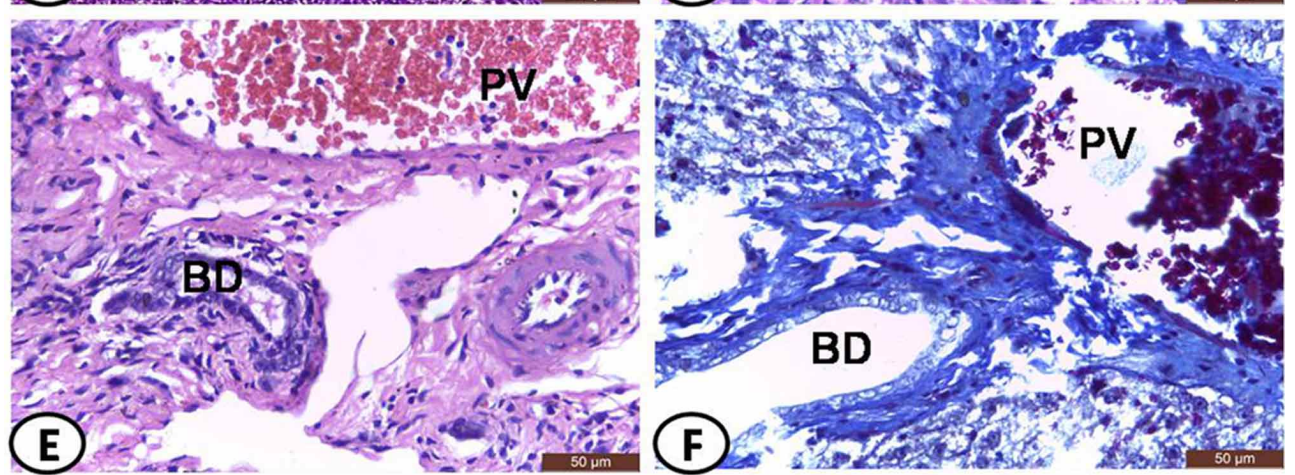
trichrome stain. Scale bars: $(A)=100 \mu \mathrm{m} ;(B, C)=200$ $\mu \mathrm{m} ;(\mathrm{D}-\mathrm{F})=50 \mu \mathrm{m}$. 
Liver sections of group III still showed detectable interlobular connective tissue septa (Figs. 2A, B) but, fewer and thinner than livers sections of positive control group. Slight reductions of fibrous tissue were detected within the portal area in comparison to positive control group (Figs. 2C, D). Moreover, congestion of the central veins (Fig. 2A) and portal vein and inflammatory cells infiltration (Fig. 2C) were still present. Also, the hepatocytes showed degeneration with cytoplasmic vacuolation (Fig. 2C).

Liver section taken from group IV revealed no nodular parenchyma due to absence of detectable fibrous septa (Fig. 3A). The fibrous deposition was decreased and concentrated only in the portal area (Fig. 3B). Improvement of the hepatocytes was noticed especially around the cen- tral veins as well as few numbers of Macrophagocytus stellatus (Kupffer cells) were detected compared to positive control group but congestion of blood sinusoids was still present (Fig. 3C).

Liver sections obtained from group $\mathrm{V}$ showed nearly normal feature of the liver, where there was no identified interlobular septa (Fig. 4A) but, only few amount of fibrous deposition within the portal area was identified (Fig. 4B). The hepatocytes showed improvement where the cells were arranged into normal pattern of hepatic cords (Fig. 4A) as well as, the hepatocytic cytoplasm showed no vacuolation especially those around the central veins (Fig. 4C). Congestion of blood sinusoids (Figs. 4A, C) and portal vein (Fig. 4B) were still identified.
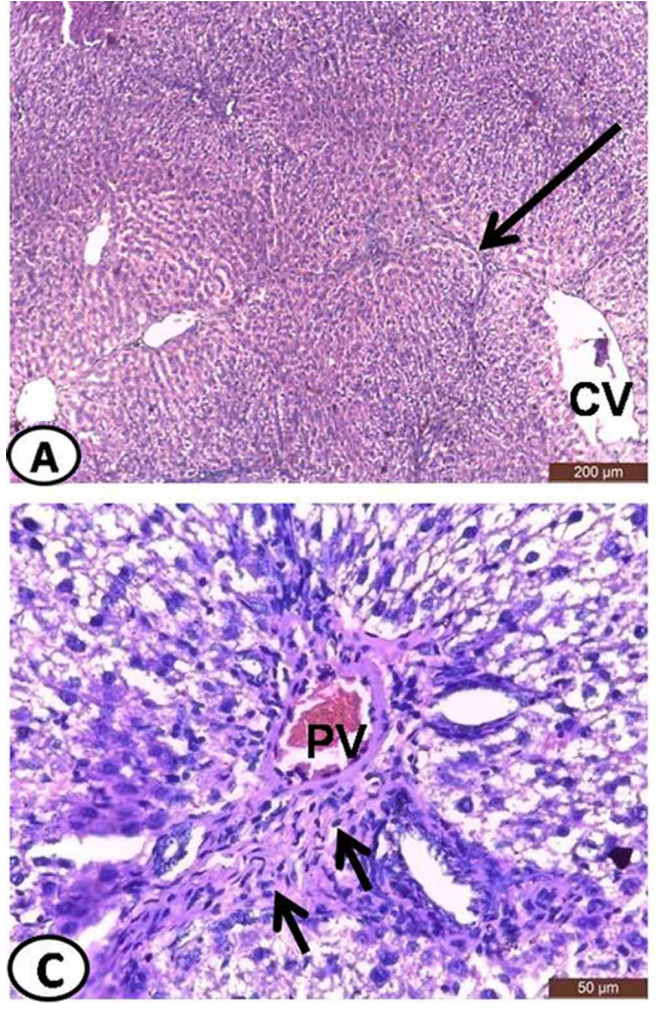
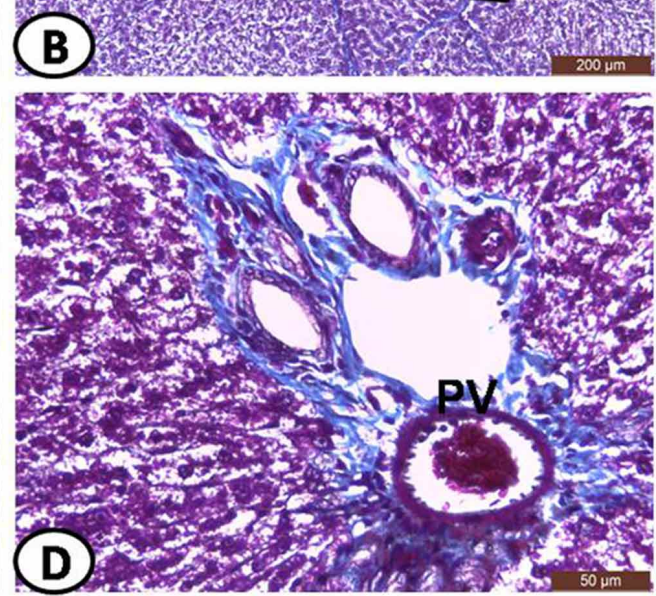

Fig. 2. Representative photomicrographs of livers obtained from probiotics treated group (A-D). Long arrow, interlobular septa; CV, central vein; short arrow, inflammatory cells; PV, portal vein. All sections stained with H\&E except Fig. D stained with Masson's trichrome stain. Scale bars: $(A, B)=200 \mu \mathrm{m} ;(C, D)=50$ $\mu \mathrm{m}$.
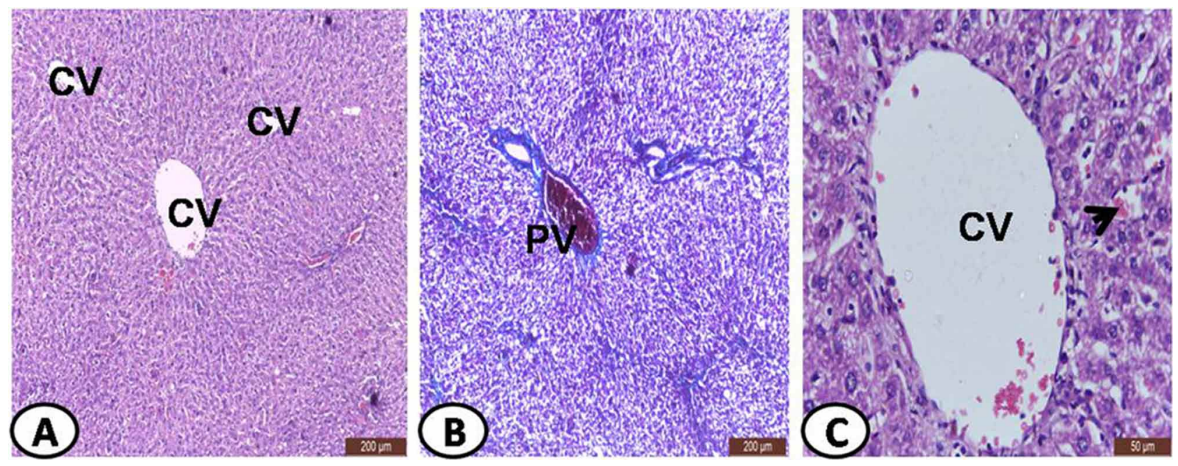

Fig. 3. Representative photomicrographs of livers obtained from silymarin treated group (A-C). PV, portal vein; CV, central vein; blood sinusoids, arrowhead. All sections stained with H\&E except Fig. B stained with Masson's trichrome stain. Scale bars: $(\mathrm{A}, \mathrm{B})=200 \mu \mathrm{m} ;(\mathrm{C})=$ $50 \mu \mathrm{m}$. 


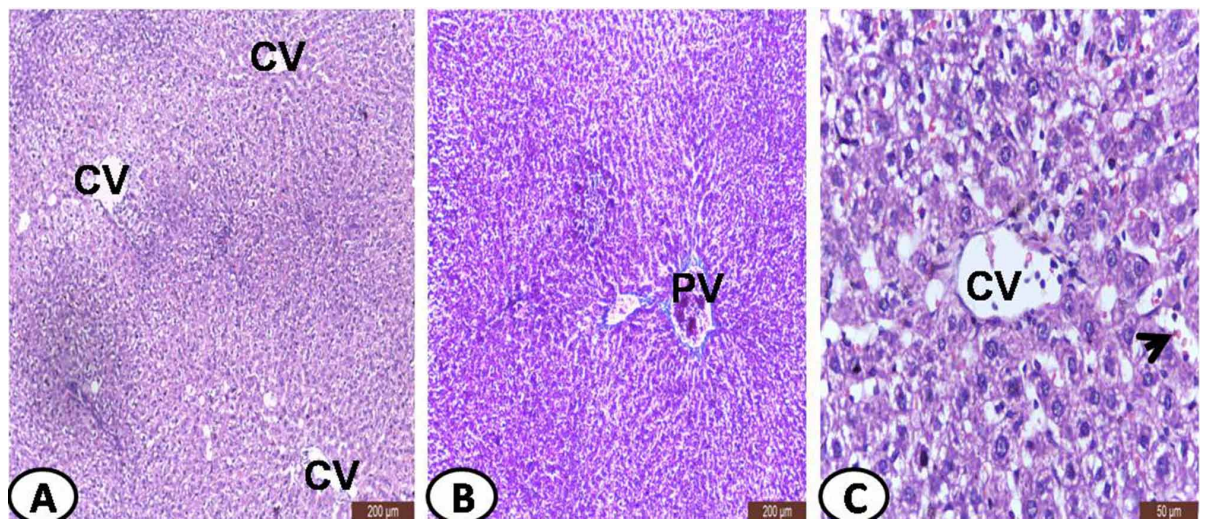

Fig. 4. Representative photomicrographs of livers obtained from probiotics and silymarin treated group (A-C). PV, portal vein; $\mathrm{CV}$, central vein; blood sinusoids, arrowhead. All sections stained with H\&E except Fig. B stained with Masson's trichrome stain. Scale bars: $(A, B)=200 \mu \mathrm{m}$; (C) $=50 \mu \mathrm{m}$.
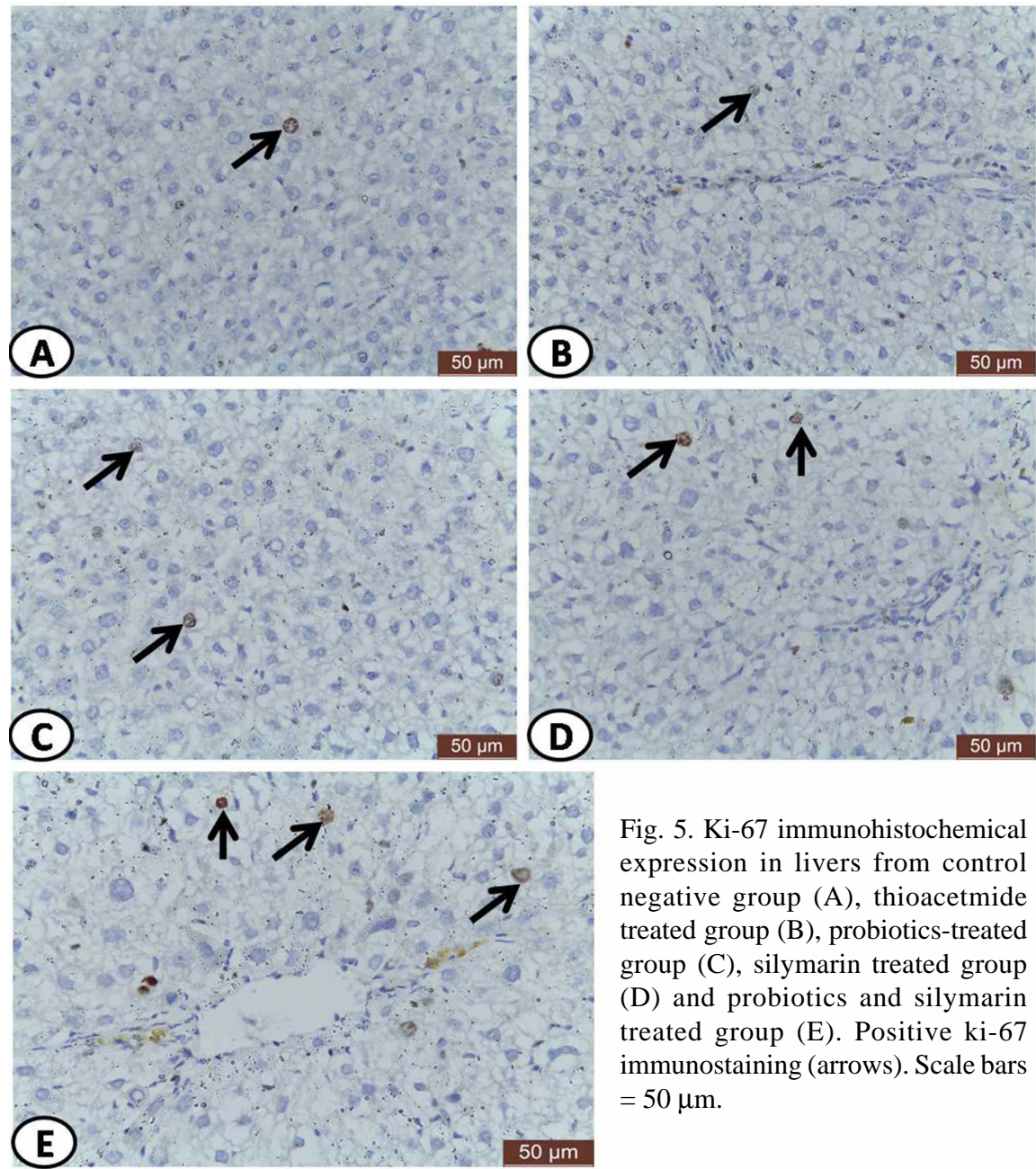

Fig. 5. Ki-67 immunohistochemical expression in livers from control negative group (A), thioacetmide treated group (B), probiotics-treated group (C), silymarin treated group (D) and probiotics and silymarin treated group (E). Positive ki-67 immunostaining (arrows). Scale bars $=50 \mu \mathrm{m}$.

Immunohistochemical findings. Ki-67 immunostaining was localized in the nuclei of the positive cells. The liver of control negative group showed few Ki-67 immunopositive cells (Fig. 5A), while the liver from probiotic and/or silymarin treated groups (Figs. 5C-E) revealed more Ki-67 immunopositive cells with mitotic figures compared to those of the control negative (Fig. 5A) and TAA groups (Fig. 5B).
Caspase 3 immunostaining was localized in the cytoplasm of the positive cells. In the TAA intoxicated liver, immunopositive cells were higher in number and showed more intense staining (Fig. 6B) than those in the control negative (Fig. 6A) and the other treated groups (Figs. 6C-E). The most affected hepatocytes were those around the central veins as they showed intense caspase 3 immunostaining (Fig. 6B). 

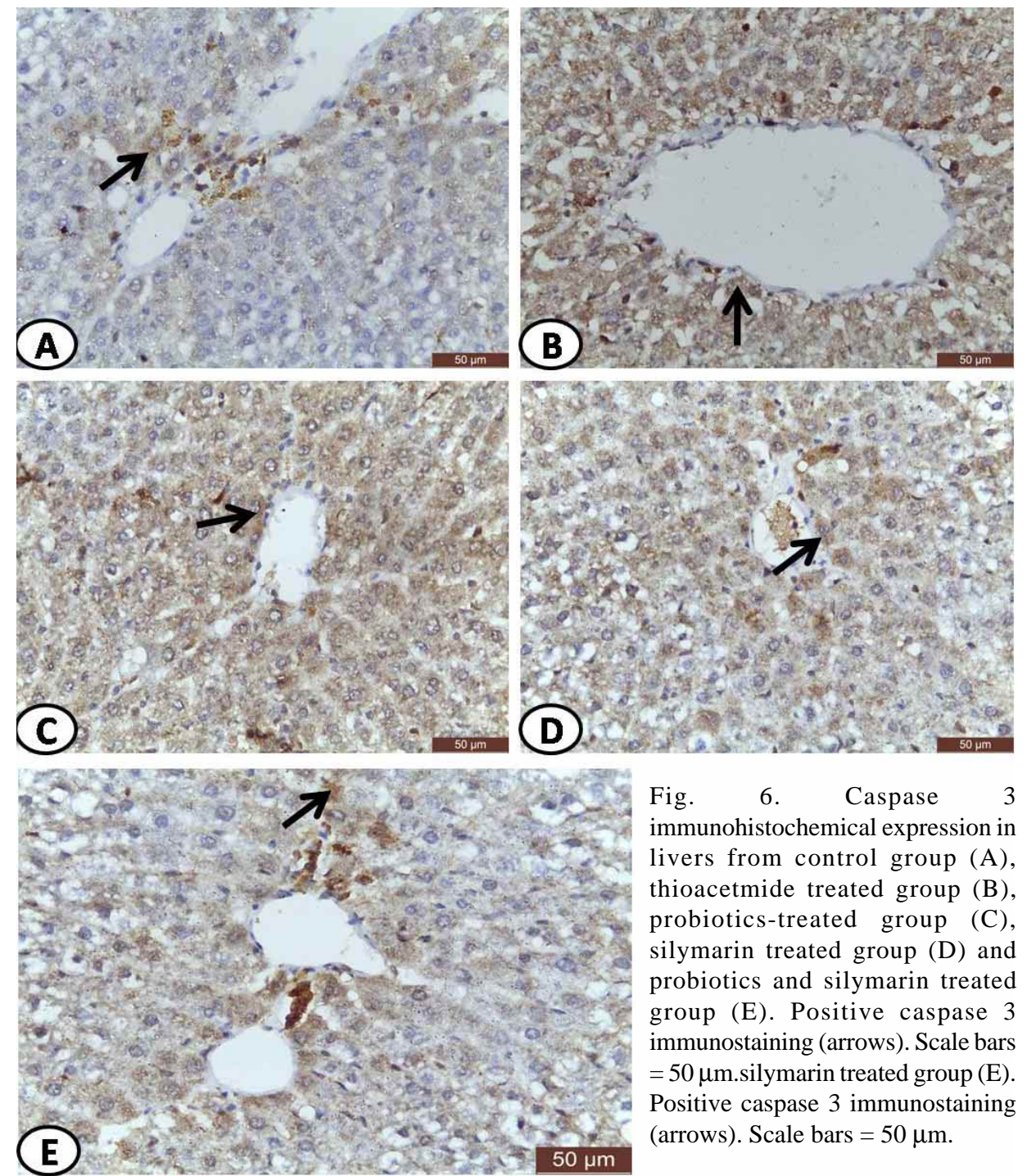

Fig. $\quad$ 6. Caspase 3 immunohistochemical expression in livers from control group (A), thioacetmide treated group (B), probiotics-treated group (C), silymarin treated group (D) and probiotics and silymarin treated group (E). Positive caspase 3 immunostaining (arrows). Scale bars $=50 \mu \mathrm{m}$. silymarin treated group $(\mathrm{E})$. Positive caspase 3 immunostaining (arrows). Scale bars $=50 \mu \mathrm{m}$.

\section{DISCUSSION}

The current study showed abnormal histological features of the liver of rats treated with TAA in comparison to normal liver. Sadasivan et al. (2006), described the hepatic damage, after TAA administration, ranging from parenchymal cell necrosis and liver cell proliferation, to the production of pseudolobules and nodular cirrhosis. In our study, liver of rats treated with TAA showed degeneration of hepatocytes with vacuolar cytoplasm, and periportal inflammatory cell infiltration with intense centrilobular necrosis, and congestion of blood sinusoids and central veins that was similar to finding of Chen et al. (2008). Also, pseudolobular hepatic parenchyma and numerous thick interlobular septa were detected in our study that was in consistence with Al-Attar, (2011). In our study, fibrosis of the portal area, inflammatory cells infiltration, and Macrophagocytus stellatus (Kupffer cells) proliferation were noticeable and identical to findings of Nada et al. (2015) and Wang et al. (2016a). Both inflammatory and Kupffer cells play a critical role in the regulation of liver inflammation (Wynn \& Barron, 2010). Additionally, Macrophagocytus stellatus (Kupffer cells) release fibrogenic transforming growth factor (TGF- $\beta 1$ ) leading to collagen deposition (Bataller \& Brenner). These marked hepatotoxic effect of TAA is not for the compound itself but due to its metabolites (TAA-S-dioxide) which initiates necrosis (Yogalakshmi et al., 2010) and bind to other intracellular molecules causing oxidative stress (Wang et al., 2016b) generating reactive oxygen species (ROS) responsible for oxidative stress (Pallottini et al., 2006). 
In probiotic treated group, the hepatic damage caused by TAA was slightly improved as well as, a slight reduction of fibrous tissue deposition was noticed compared to TAA group. However, D'Argenio et al. (2013) reported that FB ( $L$. paracasei B21060, L- glutamine, Arabinogalactan and Xilooligosaccharides) has a significant marked reduction effect on liver fibrosis in rats injected with ccl4. Also, Velayudham et al. and Gupta et al. (2013) found that probiotics reduce the progression of fibrosis in a model of steatohepatitis in rats. This variety in the effectiveness of probiotics in the different studies may depend on formulation of probiotics (Paolella $e t$ al., 2014). Furthermore, Sanders et al. stated that different doses, strain combinations, and other components like, prebiotics may be affect the health outcomes of probiotics. Both Tilg \& Hotamisligil (2006) and Takei reported the hepatoprotective effect of probiotics intake on liver activity in probiotics treated group compared to TAA-treated group. This improvement may occur as probiotics prevent the production and/uptake of lipopolysaccharides in the gut therefore, reducing levels of low grade inflammation (Gratz et al., 2010).

Silymarin treated group showed almost normal hepatic parenchyma without appearance of pseudolobulation. This finding indicates the ability of silymarin to inhibit the stage of pseudolobule formation and decrease the amount of fibrous tissue that was supported by Popescu et al. (2010) and Fatima et al. (2013). This effect occurs due to silymarin inhibits transformation of stellate cells into myofibroblasts reducing the collagen fibers deposition (Abdo et al., 2016). From previous studies, we can conclude that silymarin has a good recovery effect on fibrosis regardless the causative agents where Fatima et al. stated the effect of silmaryin of fibrosis induced by TAA while Popescu et al., stated that in ccl4 and alcohol induced fibrosis. Also, improvement of the hepatocytes was noticed where the vacuolar degeneration and inflammatory cells infiltration were decreased that was in consistence with Amin et al. (2012). This improvement was due to the effects of silymarin as cell membrane stabilizer, permeability regulator that prevents hepatotoxic agents from entering hepatocytes, promoter of ribosomal RNA synthesis, and enhancer of liver regeneration (El Mesallamy et al., 2011; Abdo et al.) as well as, it inhibits the cytochrome p450 detoxification system and prevents the metabolism of toxic TAA (Papetti et al., 2002). Beside its antioxidant properties (Gazák et al., 2007), silymarin has anti-fibrotic and antiinflammatory effects (Karimi et al., 2011).

The combination of probiotics and silymarin in treatment of TAA induced hepatotoxicity showed more improvement of the histological structure of the liver than treatment with probiotics or silymarin alone. No interlobular septa, normal pattern of hepatic cords, and normal hepatocytes especially around the central veins were detected. However, few fibrous tissues within the portal area, vacuolar degeneration in hepatocytes close to portal area, and congestion of portal vein were still identified. It was interesting that, we can conclude that combination of probiotics and silymarin potentiate each other as anti-inflammatory, antioxidant and anti-fibrotic agents.

To assess the amelioration potential of probiotics and/ or silymarin on treatment and recovery of TAA intoxicated liver, immunohistochemical staining of Ki-67 and caspase 3 was performed to evaluate the proliferative and apoptotic status of the hepatocytes.

In the current work, the limited number of Ki-67 immunopositive cells in the liver of control group was in agreement with Youssef et al. (2012), which reflects a normal homeostasis turnover of the liver. In TAA intoxicated liver, hepatocytes shows low proliferative capacity where their replication activity is reached after many cycles of injury and repair (Trak-Smayra et al., 2004). Also, Clouston et al. (2005), indicated that proliferation of hepatocytes and liver regeneration are suppressed in fibrotic injured livers compared to non-fibrotic ones. The significantly higher numbers of $\mathrm{Ki}$ 67 immunopositive cells in probiotics and/or silymarin treated groups compared to control and TAA groups was supported by Tani et al. (2001), who revealed suppressed cellular proliferation in liver of rats intoxicated with TAA. Such finding suggests that probiotics and/or silymarin enhance the regeneration of TAA-intoxicated livers via increasing the expression of ki-67 (proliferation marker) that is critical tool in evaluation of liver regeneration (Gerlach et al., 1997; Pizem et al., 2001). On contrary, Arffa et al. (2016), stated that livers of TAA intoxicated rats have increased ki-67 expression than treated groups. The findings of ki-67 immunolabeling were interesting as it revealed a higher regeneration activity of using silymarin and combination of silymarin with probiotics in treatment of TAA intoxicated liver than using probiotics alone. This result matches the histological findings suggesting that silymarin exerts more potent effect on liver regeneration predominantly through enhancing the proliferation of hepatocytes.

It is common that TAA administration in rats induces hepatic cell necrosis and apoptosis promoting fibrosis (Wang et al., 2016b) therefore, we used caspase 3 immunostaining as a tool for apoptosis detection. Our results demonstrated more intense caspase 3 immunostaining in hepatocytes around the central veins indicating a centrilobular necrosis of the liver intoxicated by TAA as mentioned by Omneia et al. (2014). Inactivation of caspases protects hepatocytes against apoptosis, reduces cytokines involved in inflammatory signaling, and ameliorates fibrogenesis (Dixon et al., 2012; 
Thapaliya et al., 2014). It was interesting that probiotics and/ or silymarin have apoptosis inhibitor effect where the livers from probiotics and/or silymarin treated groups revealed low apoptotic rats compared to TAA intoxicated group. In contrast to our results, Kadir et al. (2013) detected low apoptotic rate immunohistochemically in liver of TAA group.

Stimulation of hepatocytes proliferation and inhibition of apoptosis are tightly correlated with the restoration of liver structure. Our results showed an increase of Ki-67 expression (marked as liver regeneration) but a decrease of caspase 3 expression (marked as liver apoptosis) was detected in livers of rats treated with probiotics and/or silymarin treatment than TAA intoxicated rats.

CONCLUSION: The current work reveals the ameliorative potential effect of probiotics and/or silymarin on the structure of TAA intoxicated livers in rats through enhancing proliferation and reducing apoptosis of hepatocytes in rats. Also, it was remarkable that treatment with silymarin and combination of probiotics and silymarin are more potent as antifibrotic agents than using probiotics alone that was proved histologically and immunohistochemically.

EMAM, M. A.; FAROUK, S. M. \& ABDO, M. El potencial de mejora de los probióticos y / o silimarina sobre la hepatotoxicidad inducida por tioacetamida en ratas: Estudio histológico e inmunohistoquímico. Int. J. Morphol., 36(2):661-669, 2018.

RESUMEN: La tioacetamida (TAA) es uno de los agentes fungicidas más comunes que inducen lesiones hepáticas que varían desde inflamación, necrosis y fibrosis hasta cirrosis. Muchos estudios recientes informaron el efecto beneficioso de los probióticos y la silimarina sobre la hepatotoxicidad independientemente de los agentes causantes. Por lo tanto, el presente estudio tuvo como objetivo evaluar el papel paliativo de los probióticos y / o silimarina en la hepatotoxicidad inducida por TAA en ratas a través de métodos histológicos e inmunohistoquímicos. Para este experimento se usaron veinticinco ratas albinas y se dividieron en cinco grupos ( $\mathrm{n}=5$ ratas / grupo); el grupo I se usó como control negativo; en el grupo II se administró por vía oral agua destilada durante seis semanas y luego se inyectó TAA $(200 \mathrm{mg} / \mathrm{kg}$ b.wt./ $5 \mathrm{ml}$ solución salina fisiológica / IP) dos veces por semana durante otras seis semanas; el grupo III se trató con probióticos, dosis diaria de $135 \mathrm{mg} / \mathrm{kg}$ b.wt. por vía oral en agua potable, durante seis semanas y luego fue inyectado con TAA (dosis del grupo II), dos veces por semana durante otras seis semanas; el grupo IV se trató con silimarina, con una dosis de $200 \mathrm{mg} / \mathrm{kg}$ b.wt por vía oral 4 veces por semana durante seis semanas, luego se inyectó TAA (dosificación del grupo II), dos veces por semana durante otras seis semanas; y el grupo $\mathrm{V}$, se trató con una combinación de ambos probióticos y silimarina con la misma dosis que en los grupos III y IV, respectivamente, luego fueron inyectados con TAA (dosificación del grupo II), dos veces por semana durante otras seis semanas. Histológicamente, la TAA indujo la degeneración de los hepatocitos, la infiltración de células inflamatorias y el parénquima pseudolobular, así como también una apoptosis alta y tasas de proliferación bajas que se probaron mediante tinción inmunohistoquímica para caspasa 3 y ki-67, respectivamente. Los probióticos y / o la silimarina mejoraron la característica histológica de los hepatocitos, redujeron la apoptosis y estimularon la proliferación. En base a estos resultados, concluimos que el uso de la combinación de probióticos y silimarina mejora el efecto hepatotóxico del TAA en ratas más que el uso de probióticos o silimarina individualmente.

PAlabraS ClaVE: Tioacetamida; Probióticos; Silimarina; Hígado; Histología, Inmunohistoquímica.

\section{REFERENCES}

Abdo, F. K.; Ahmed, F. E.; Alazouny, Z. M. \& Hassan, S. M. Silymarin versus gold nanoparticles efficacy in ameliorating CCl4-induced liver fibrosis in adult male Albino rats: A histological and immunohistochemical study. $\mathrm{Br}$. J. Sci., 13(2):13-23, 2016.

Amin, Z. A.; Bilgen, M.; Alshawsh, M. A.; Ali, H. M.; Hadi, A. H. A. \& Abdulla, M. A. Protective role of Phyllanthus niruri extract against thioacetamideinduced liver cirrhosis in rat model. Evid. Based Complement. Altern. Med., (2012):241583, 2012.

Anukam, K. C.; Osazuwa, E. O. \& Reid, G. Knowledge of probiotics by Nigerian clinicians. Int. J. Probiotics Prebiotics, 1(1):57-62, 2006.

Arffa, M. L.; Zapf, M. A.; Kothari, A. N.; Chang, V.; Gupta, G. N.; Ding, X.; Al-Gayyar, M. M.; Syn, W.; Elsherbiny, N. M.; Kuo, P. C. \& Mi, Z. Epigallocatechin-3-gallate upregulates miR-221 to inhibit osteopontindependent hepatic fibrosis. PLoS One, 11(12):e0167435, 2016.

Aydin, A. F.; Küskü-Kiraz, Z.; Dogru-Abbasoglu, S.; Güllüoglu, M.; Uysal, M. \& Koçak-Toker, N. Effect of carnosine against thioacetamide-induced liver cirrhosis in rat. Peptides, 31(1):67-71, 2010.

Ayyanar, M.; Sankarasivaraman, K. \& Ignacimuthu, S. Traditional herbal medicines used for the treatment of diabetes among two major triabal groups in South Tamil Nadu, India. Ethnobot. Leafl., 12:276-80, 2008.

Bancroft, J. D. \& Gamble, M. Theory and Practice of Histological Techniques. $5^{\text {th }}$ ed. London, Churchill Livingstone, 2002.

Bataller, R. \& Brenner, D. A. Liver fibrosis. J. Clin. Invest., 115(2):209-18, 2005.

Chen, T. M.; Subeq, Y. M.; Lee, R. P.; Chiou, T. W. \& Hsu, B. G. Single dose intravenous thioacetamide administration as a model of acute liver damage in rats. Int. J. Exp. Pathol., 89(4):223-31, 2008.

Clouston, A. D.; Powell, E. E.; Walsh, M. J.; Richardson, M. M.; Demetris, A. J. \& Jonsson, J. R. Fibrosis correlates with a ductular reaction in hepatitis C: roles of impaired replication, progenitor cells and steatosis. Hepatology, 41(4):809-18, 2005

D'Argenio, G.; Cariello, R.; Tuccillo, C.; Mazzone, G.; Federico, A.; Funaro, A.; De Magistris, L.; Grossi, E.; Callegari, M. L.; Chirico, M.; Caporaso, N.; Romano, M.; Morelli, L. \& Loguercio, C. Symbiotic formulation in experimentally induced liver fibrosis in rats: intestinal microbiota as a key point to treat liver damage? Liver Int., 33(5):687-97, 2013.

Dixon, L. J.; Berk, M.; Thapaliya, S.; Papouchado, B. G. \& Feldstein, A. E. Caspase-1-mediated regulation of fibrogenesis in diet-induced steatohepatitis. Lab. Invest., 92(5):713-23, 2012.

El Mesallamy, H. O.; Metwally, N. S.; Soliman, M. S.; Ahmed, K. A. \& Abdel Moaty, M. M. The chemopreventive effect of Ginkgo biloba and Silybum marianum extracts on hepatocarcinogenesis in rats. Cancer Cell Int., 11(1):38, 2011

Fatima, S. N. \& Mahboob, T. Role of silymarin in protection of liver cirrhosis. World J. Pharm. Pharm. Sci., 3(1):73-91, 2013.

Gazák, R.; Walterová, D. \& Kren, V. Silybin and silymarin--new and emerging applications in medicine. Curr. Med. Chem., 14(3):315-38, 2007.

Gerlach, C.; Sakkab, D. Y.; Scholzen, T.; Dassler, R.; Alison, M. R. \& Gerdes, J. Ki-67 expression during rat liver regeneration after partial hepatectomy. Hepatology, 26(3):573-8, 1997.

Gratz, S. W.; Mykkanen, H. \& El-Nezami, H. S. Probiotics and gut health: a 
special focus on liver diseases. World J. Gastroenterol., 16(4):403-10, 2010.

Gupta, N.; Kumar, A.; Sharma, P.; Garg, V.; Sharma, B. C. \& Sarin, S. K. Effects of the adjunctive probiotic VSL\#3 on portal haemodynamics in patients with cirrhosis and large varices: a randomized trial. Liver Int., 33(8):114857, 2013.

Horiguchi, N.; Ishac, E. J. \& Gao, B. Liver regeneration is suppressed in alcoholic cirrhosis: correlation with decreased STAT3 activation. Alcohol, 41(4):27180, 2007.

Housková, V.; Stengl, V.; Bakardjieva, S.; Murafa, N.; Kalendová, A. \& Oplustilc, F. Nanostructure materials for destruction of warfare agents and eco-toxins prepared by homogeneous hydrolysis with thioacetamide: Part 1-zinc oxide. J. Phys. Chem. Solids, 68(5-6):716-20, 2007.

Hsieh, C. C.; Fang, H. L. \& Lina, W. C. Inhibitory effect of Solanum nigrum on thioacetamide-induced liver fibrosis in mice. J. Ethnopharmacol., 119(1):117-21, 2008.

Kadir, F. A.; Kassim, N. M.; Abdulla, M. A. \& Yehye, W. A. Hepatoprotective role of ethanolic extract of vitex negundo in thioacetamide-induced liver fibrosis in male rats. Evid. Based Complement. Alternat. Med., 2013:739850, 2013.

Karimi, G.; Vahabzadeh, M.; Lari, P.; Rashedinia, M. \& Moshiri, M. "Silymarin", a promising pharmacological agent for treatment of diseases. Iran. J. Basic Med. Sci., 14(4):308-17, 2011.

Lee, J. W.; Shin, K. D.; Lee, M.; Kim, E. J.; Han, S. S.; Han, M. Y.; Ha, H.; Jeong, T. C. \& Koh, W. S. Role of metabolism by flavin-containing monooxygenase in thioacetamide-induced immunosuppression. Toxicol. Lett., 136(3):163-72, 2003.

Mumoli, N.; Cei, M. \& Cosimi, A. Drug-related hepatotoxicity. N. Engl. J. Med., 354(20):2191-3, 2006.

Muriel, P.; Moreno, M. G.; Hernández, M. del C.; Chávez, E. \& Alcantar, L. K. Resolution of liver fibrosis in chronic $\mathrm{CCl} 4$ administration in the rat after discontinuation of treatment: effect of silymarin, silibinin, colchicine and trimethylcolchicinic acid. Basic Clin. Pharmacol. Toxicol., 96(5):375-80, 2005.

Nada, S. A.; Gowifel, A. M. H.; El-Denshary, E. E. S.; Salama, A. A.; Khalil, M. G. \& Ahmed, K. A. Protective effect of grape seed extract and/or silymarin against thioacetamide-induced hepatic fibrosis in rats. J. Liver, 4:178, 2015.

Omneia, M. A. H.; Shehata, M. E.; El-Bagoory, G. F. \& Amin, A. G. Effect of Calotropis procera extract on thioacetamide induced liver cirrhosis in rats. Benha Vet. Med. J., 27(2):126-39, 2014.

Ostapowicz, G.; Fontana, R. J.; Schiødt, F. V.; Larson, A.; Davern, T. J.; Han, S. H.; McCashland, T. M.; Shakil, A. O.; Hay, J. E.; Hynan, L.; Crippin, J. S.; Blei, A. T.; Samuel, G.; Reisch, J.; Lee, W. M. \& U. S. Acute Liver Failure Study Group. Results of a prospective study of acute liver failure at 17 tertiary care centers in the United States. Ann. Intern. Med., 137(12):94754, 2002.

Pallottini, V.; Martini, C.; Bassi, A. M.; Romano, P.; Nanni, G. \& Trentalance, A. Rat HMGCoA reductase activation in thioacetamide-induced liver injury is related to an increased reactive oxygen species content. J. Hepatol., 44(2):368-74, 2006.

Paolella, G.; Mandato, C.; Pierri, L.; Poeta, M.; Di Stasi, M. \& Vajro, P. Gutliver axis and probiotics: their role in non-alcoholic fatty liver disease. World J. Gastroenterol., 20(42):15518-31, 2014.

Papetti, A.; Daglia, M. \& Gazzani, G. Anti- and pro-oxidant activity of water soluble compounds in Cichorium intybus var. silvestre (Treviso red chicory). J. Pharm. Biomed. Anal., 30(4):939-45, 2002.

Pizem, J.; Marolt, V. F.; Luzar, B. \& Cör, A. Proliferative and apoptotic activity in hepatocellular carcinoma and surrounding non-neoplastic liver tissue. Pflugers Arch., 442(6 Suppl. 1):R174-6, 2001.

Pohanish, R. P. Sittig's Handbook of Toxic and Hazardous Chemicals and Carcinogens. 6th ed. New York, Elsevier, 2012. pp.2552.

Popescu, R.; Verdes, D.; Filimon, M. N. \& Gotia, L. S. Protective effect of Silybin in rats liver toxicity. Anim. Sci. Biotechnol., 43(1):506-10, 2010.

Sadasivan, S.; Latha, P. G.; Sasikumar, J. M.; Rajashekaran, S.; Shyamal, S. \& Shine, V. J. Hepatoprotective studies on Hedyotis corymbosa (L.) Lam. J. Ethnopharmacol., 106(2):245-9, 2006.

Sanders, M. E.; Klaenhammer, T. R.; Ouwehand, A. C.; Pot, B.; Johansen, E.;
Heimbach, J. T.; Marco, M. L.; Tennilä, J.; Ross, R. P.; Franz, C.; Pagé, N.; Pridmore, R. D.; Leyer, G.; Salminen, S.; Charbonneau, D.; Call, E. \& Lenoir-Wijnkoop, I. Effects of genetic, processing, or product formulation changes on efficacy and safety of probiotics. Ann. N. Y. Acad. Sci., 1309:118, 2014.

Stickel, F. \& Schuppan, D. Herbal medicine in the treatment of liver diseases. Dig. Liver Dis., 39(4):293-304, 2007.

Takei, Y. Treatment of non-alcoholic fatty liver disease. J. Gastroenterol. Hepatol., 28 Suppl. 4:79-80, 2013.

Tani, Y.; Kamai, Y.; Yamate, K.; Mizuno, H.; Yamamoto, H.; Hosokawa, T. \& Doi, K. Restitutive response of Mini rat liver to injury induced by a single oral administration of thioacetamide. J. Toxicol. Sci., 26(1):25-37, 2001.

Thapaliya, S.; Wree, A.; Povero, D.; Inzaugarat, M. E.; Berk, M.; Dixon, L.; Papouchado, B. G. \& Feldstein, A. E. Caspase 3 inactivation protects against hepatic cell death and ameliorates fibrogenesis in a diet-induced NASH model. Dig. Dis. Sci., 59(6):1197-206, 2014.

Thyagarajan, S. P.; Jayaram, S.; Gopalakrishnan, V.; Hari, R.; Jeyakumar, P. \& Sripathi, M. S. Herbal medicines for liver diseases in India. J. Gastroenterol. Hepatol., 17 Suppl. 3:S370-6, 2002.

Tilg, H. \& Hotamisligil, G. S. Nonalcoholic fatty liver disease: Cytokineadipokine interplay and regulation of insulin resistance. Gastroenterology, 131(3):934-45, 2006.

Trak-Smayra, V.; Contreras, J.; Dondero, F.; Durand, F.; Dubois, S.; Sommacale, D.; Marcellin, P.; Belghiti, J.; Degott, C. \& Paradis, V. Role of replicative senescence in the progression of fibrosis in hepatitis $\mathrm{C}$ virus $(\mathrm{HCV})$ recurrence after liver transplantation. Transplantation, 77(11):1755-60, 2004.

Velayudham, A.; Dolganiuc, A.; Ellis, M.; Petrasek, J.; Kodys, K.; Mandrekar, P. \& Szabo, G. VSL\#3 probiotic treatment attenuates fibrosis without changes in steatohepatitis in a diet-induced nonalcoholic steatohepatitis model in mice. Hepatology, 49(3):989-97, 2009.

Wallace, K.; Burt, A. D. \& Wright, M. C. Liver fibrosis. Biochem. J., 411(1):118, 2008.

Wang, H.; Zhang, H.; Zhang, Z.; Huang, B.; Cheng, X.; Wang, D.; la Gahu, Z.; Xue, Z.; Da, Y.; Li, D.; Yao, Z.; Gao, F.; Xu, A. \& Zhang, R. Adiponectinderived active peptide ADP355 exerts anti-inflammatory and anti-fibrotic activities in thioacetamide-induced liver injury. Sci. Rep., 6:19445, 2016 a.

Wang, P.; Koyama, Y.; Liu, X.; Xu, J.; Ma, H. Y.; Liang, S.; Kim, I. H.; Brenner, D. A. \& Kisseleva, T. Promising therapy candidates for liver fibrosis. Front. Physiol., 7:47, 2016b.

Wynn, T. A. \& Barron, L. Macrophages: master regulators of inflammation and fibrosis. Semin. Liver Dis., 30(3):245-57, 2010.

Yogalakshmi, B.; Viswanathan, P. \& Anuradha, C. V. Investigation of antioxidant, anti-inflammatory and DNA-protective properties of eugenol in thioacetamide-induced liver injury in rats. Toxicology, 268(3):204-12, 2010.

Youssef, M. I.; Maghraby, H.; Youssef, E. A. \& El-Sayed, M. M. Expression of $\mathrm{Ki} 67$ in hepatocellular carcinomainduced by diethylnitrosamine in mice and its correlation with histopathological alterations. J. Appl. Pharm. Sci., 2(3):52-9, 2012.

\section{Corresponding author: \\ Dr. Mohamed Abdo \\ Anatomy and Embryology Department \\ Faculty of Veterinary Medicine \\ University of Sadat City, 32511 \\ EGYPT}

\section{Email: mohamed.abdo@vet.usc.edu.eg}

Received: $30-10-2017$

Accepted: 24-01-2018 